\title{
Bacterial Communities in Boreal Forest Mushrooms Are Shaped Both by Soil Parameters and Host Identity
}

\author{
Mari Pent ${ }^{1}$, Kadri Põldmaa ${ }^{1 *}$ and Mohammad Bahram ${ }^{1,2}$ \\ 'Department of Botany, Institute of Ecology and Earth Sciences, University of Tartu, Tartu, Estonia, ${ }^{2}$ Department of \\ Organismal Biology, Evolutionary Biology Centre, Uppsala University, Uppsala, Sweden
}

Despite recent advances in understanding the microbiome of eukaryotes, little is known about microbial communities in fungi. Here we investigate the structure of bacterial communities in mushrooms, including common edible ones, with respect to biotic and abiotic factors in the boreal forest. Using a combination of culture-based and Illumina high-throughput sequencing, we characterized the bacterial communities in fruitbodies of fungi from eight genera spanning four orders of the class Agaricomycetes (Basidiomycota). Our results revealed that soil pH followed by fungal identity are the main

OPEN ACCESS

Edited by:

Tim Daniell,

James Hutton Institute, UK

Reviewed by:

Mohamed Hijri,

Université de Montréal, Canada

Unni Vik,

University of Oslo, Norway

Aurelie Deveau,

Institut National de la Recherche

Agronomique, France

*Correspondence:

Kadri Põldmaa

hypomyc@ut.ee

Specialty section

This article was submitted to

Terrestrial Microbiology,

a section of the journal

Frontiers in Microbiology

Received: 31 December 2016

Accepted: 24 April 2017

Published: 10 May 2017

Citation:

Pent M, Põldmaa K and Bahram M

(2017) Bacterial Communities

in Boreal Forest Mushrooms Are

Shaped Both by Soil Parameters

and Host Identity.

Front. Microbiol. 8:836.

doi: 10.3389/fmicb.2017.00836 determinants of the structure of bacterial communities in mushrooms. While almost half of fruitbody bacteria were also detected from soil, the abundance of several bacterial taxa differed considerably between the two environments. The effect of host identity was significant at the fungal genus and order level and could to some extent be ascribed to the distinct bacterial community of the chanterelle, representing Cantharellalesthe earliest diverged group of mushroom-forming basidiomycetes. These data suggest that besides the substantial contribution of soil as a major taxa source of bacterial communities in mushrooms, the structure of these communities is also affected by the identity of the host. Thus, bacteria inhabiting fungal fruitbodies may be nonrandomly selected from environment based on their symbiotic functions and/or habitat requirements.

Keywords: Agaricales, Boletales, ectomycorrhizal fungi, food microbiome, microbial interactions, Proteobacteria, Russulales, symbiont communities

\section{INTRODUCTION}

Bacteria are ubiquitous microbes in many host and non-host environments, where they play essential roles in nutrient cycling. In eukaryotic hosts, bacteria may also perform various pathogenic and mutualistic functions, such as improving nutrient uptake, growth, and protection of their hosts against pathogens (Eckburg et al., 2006; Grice et al., 2009; Hacquard and Schadt, 2014; Vandenkoornhuyse et al., 2015). Besides their ecological importance, bacteria colonizing edible plants or animals may also impact conservation and healthfulness of derived food products. For example, several probiotic and bacteria antagonistic to human pathogens have been found in fresh fruits, vegetables and truffles (Trias et al., 2008; Vitali et al., 2012; Saidi et al., 2015). Despite the increasing knowledge of the microbiome in eukaryotes (Bäckhed et al., 2005; Grube et al., 2009; Fan et al., 2012; Bulgarelli et al., 2013; Hyde et al., 2016), many major host groups remain little studied in this regard. 
Fungi represent a highly diverse group of eukaryotes occurring in most ecosystems. The most conspicuous fungi include mushrooms with aboveground spore-forming structures (fruitbodies) in various groups of Basidiomycota and certain Ascomycota. Some members of these two phyla are economically important sources of food and medicine for humans. Although mushrooms have one of the largest fruitbodies among fungi, potentially harboring highly diverse bacteria, evidence of their microbiome is limited and almost exclusively to taxa that grow in pure culture (Rangel-Castro et al., 2002a; Tsukamoto et al., 2002; Kumari et al., 2013). Only a few studies have analyzed mushrooms from different genera in this regard (Zagriadskaia et al., 2013; de Carvalho et al., 2015). More comprehensive studies on characterizing the bacterial communities using next generation sequencing methods have focused of truffles and similar ascomycetes with belowground fruitbodies (e.g., AntonyBabu et al., 2014; Benucci and Bonito, 2016). Bacteria may have several symbiotic functions in mushrooms, such as inhibiting pathogens and antagonists (Tsukamoto et al., 2002; Frey-Klett et al., 2007), improving the distribution of spores (Citterio et al., 2001; Splivallo et al., 2014) or providing vitamins and growth regulators (Rangel-Castro et al., 2002a; Riedlinger et al., 2006). Several fungal-associated bacteria are also known to fix nitrogen (Jayasinghearachchi and Seneviratne, 2004; Paul et al., 2007; Barbieri et al., 2010; Hoppe et al., 2014), although there is yet no evidence that the fungus directly benefits from that ability of the associated bacteria. Increasing evidence shows that fruitbody formation in mushrooms can be triggered (Noble et al., 2009) or inhibited (Munsch et al., 2002; Yun et al., 2013) by bacteria. The exploration of fungal microbiome can thus be useful for improving the yield of cultivated mushrooms (Cho et al., 2003; Barbieri et al., 2010; Kataoka et al., 2012) and for identifying bacteria antagonistic to fungal pathogens (De Boer et al., 2005; Bandara et al., 2006).

Similar to the pattern observed in several eukaryotes that share their microbiota with that of the surrounding environment (Fan et al., 2012; Jeon et al., 2013), a large proportion of bacteria in mushrooms could be adopted from their environment. Majority of the lifecycle of mushrooms occurs in the form of mycelia in their substrata, mainly soil, whereas fruitbodies are mostly formed above the ground. Soil contains diverse bacterial communities (Fierer and Jackson, 2006; Rousk et al., 2010), that provide a species pool for the microbiomes of soil-inhabiting organisms (Antony-Babu et al., 2014; Deveau et al., 2016). Thus, environmental forces that shape bacterial community composition in soil may indirectly contribute to the structure of bacterial communities in fungal mycelia and fruitbodies (Warmink et al., 2009; Antony-Babu et al., 2014). In case of mushrooms, acquisition of bacteria from air has also been suggested (Zagriadskaia et al., 2013). In addition to abiotic factors, host identity has been observed to affect the community composition of mycorrhiza-helper bacteria (Poole et al., 2001; Frey-Klett et al., 2007) as well as that of bacteria in the mycosphere (Warmink et al., 2009) and fungal fruitbodies (Dahm et al., 2005; Kumari et al., 2013). In particular, fruitbodies of different fungal taxa create various specific conditions that filter certain bacteria from the surrounding bulk soil and the mycosphere (Boersma et al., 2009, 2010; Antony-Babu et al., 2014). Such selectivity has been observed in plants, which select bacteria present in soil depending on host's genotype (Vandenkoornhuyse et al., 2015), rhizodeposits (Bulgarelli et al., 2013), and several niche-specific factors such as temperature, $\mathrm{pH}$, oxygen levels, and organic carbon availability (Bulgarelli et al., 2013; Hacquard et al., 2015).

In this study, we aimed to characterize the bacterial communities of mushrooms in boreal forests and to understand the factors shaping their structure. In particular, our main goal was to examine the impact of fungal identity, habitat, and soil type as well as soil parameters on the bacterial community composition in fungal fruitbodies. We hypothesized that these communities originate from underlying soils, hence the bacterial community structure in mushrooms depends mainly on soil characteristics. To test this hypothesis, we compared the bacterial communities in fruitbodies of ectomycorrhizal (EcM) fungi from four main mushroom-forming fungal orders as well as in the adjacent soil, using a combination of culture-based and highthroughput sequencing (HTS).

\section{MATERIALS AND METHODS}

\section{Study Sites and Fruitbody Sampling}

Fungal fruitbodies were collected in boreal forests at three nature reserves in Eastern Estonia in September-October 2014 and 2015. Altogether four $2,500 \mathrm{~m}^{2}$ plots, located in three nature reserves, were sampled from each of the three habitat types (Supplementary Table S1). Mushrooms were identified to 15 EcM species (except for unidentified Russula spp.) from the four main orders of mushroom-forming fungi (Basidiomycota). The number of fruitbodies collected depended on their presence at each site; in case no fruitbodies were found for a particular species, fruitbodies of congeneric species were sampled (Table 1). Only mature fruitbodies were sampled, excluding immature and decaying mushrooms from our selection. All fruitbodies were packed individually in foil, transported to the lab in a cooled container and kept in fridge at $4^{\circ} \mathrm{C}$ until being handled in a laminar flow chamber.

\section{Soil Characteristics}

Soil samples originated from the same sites as the mushrooms and were collected according to the methodology described by Tedersoo et al. (2014). Briefly, two soil samples were collected near the base of each of the 20 trees growing at nearly equal distance from each other and the 40 soil samples from a site were pooled for all subsequent analyses. The fruitbodies were collected from close proximity to the selected trees, if possible. The concentrations of organic matter, carbon (C), nitrogen $(\mathrm{N}), \delta^{15} \mathrm{~N}$, phosphorus $(\mathrm{P})$, potassium $(\mathrm{K})$, calcium $(\mathrm{Ca})$, and magnesium $(\mathrm{Mg})$ were found as described by Tedersoo et al. (2012). $\delta^{15} \mathrm{~N}$ was included in our analysis as a measure of nitrogen availability. Soil $\mathrm{pH}$ was measured in $1 \mathrm{M} \mathrm{KCl}$ solution. Soil types and parameters are listed in Supplementary Table S2. 
TABLE 1 | Mushrooms taxonomic identity and number of fruitbodies sampled at each site.

\begin{tabular}{|c|c|c|c|c|c|c|c|}
\hline \multirow[t]{2}{*}{ Order } & \multirow[t]{2}{*}{ Family } & \multirow[t]{2}{*}{ Genus } & \multirow[t]{2}{*}{ Species } & \multicolumn{2}{|c|}{ Number of analyzed fruitbodies } & \multicolumn{2}{|c|}{ Number of sites } \\
\hline & & & & HTS $^{a}$ & Culture & HTS & Culture \\
\hline Agaricales & Amanitaceae & Amanita & A. fulva & 18 & 23 & 7 & 6 \\
\hline Agaricales & Amanitaceae & Amanita & A. muscaria & 0 & 1 & 0 & 1 \\
\hline Agaricales & Amanitaceae & Amanita & A. rubescens & 0 & 1 & 0 & 1 \\
\hline Agaricales & Cortinariaceae & Cortinarius & C. caperatus & 14 & 6 & 4 & 3 \\
\hline Agaricales & Cortinariaceae & Cortinarius & C. armillatus & 10 & 9 & 4 & 4 \\
\hline Cantharellales & Cantharellaceae & Cantharellus & C. cibarius & 12 & 12 & 5 & 5 \\
\hline Boletales & Boletaceae & Leccinum & L. holopus & $7(2)$ & 7 & 3 & 3 \\
\hline Boletales & Boletaceae & Leccinum & L. scabrum & 8 & 4 & 3 & 3 \\
\hline Boletales & Boletaceae & Leccinum & L. variicolor & 6 & 3 & 2 & 2 \\
\hline Boletales & Paxillaceae & Paxillus & P. involutus & 9 & 5 & 3 & 2 \\
\hline Boletales & Suillaceae & Suillus & S. bovinus & 17 & 15 & 5 & 4 \\
\hline Boletales & Suillaceae & Suillus & S. variegatus & $22(1)$ & 18 & 9 & 7 \\
\hline Russulales & Russulaceae & Russula & R. decolorans & 11 & 13 & 4 & 5 \\
\hline Russulales & Russulaceae & Russula & Russula spp. b & 21 & 19 & 7 & 8 \\
\hline Russulales & Russulaceae & Lactarius & L. quieticolor & 3 & 3 & 1 & 1 \\
\hline Russulales & Russulaceae & Lactarius & L. rufus & 25 & 38 & 8 & 9 \\
\hline
\end{tabular}

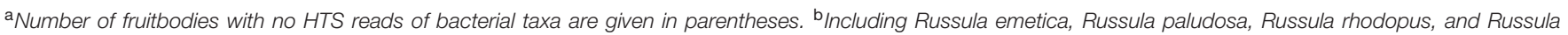
vinosa.

\section{Culturing}

To avoid contaminations, only intact tissue from inside mushrooms was allocated for analyses. For that purpose, fruitbody samples were cut lengthwise using a sterile scalpel, followed by sterilizing the cut surface of the two halves under the UV light for $5 \mathrm{~min}$ to avoid cross contamination. The second round of cuts was made along the cut surface of the cap, the central part and along the lower part of the stipe. Care was taken to avoid contact with the surface of the fruitbody. The scalpel was flame-sterilized before every single cut. Using a sterile drill, two $5 \mathrm{~mm}^{3}$ pieces of fungal tissue were taken from each of the three double-cut areas at the longitudinal section.

Two sets of three pieces (one from the cap and one from the middle part and one from the lower part of the stipe) from each fruitbody were separated into two $1.5 \mathrm{ml}$ Eppendorf tubes, one of which was kept at $-20^{\circ} \mathrm{C}$ for HTS. In the other, containing $400 \mu \mathrm{l}$ of $0.1 \mathrm{M}$ phosphate buffer (1 M SmartMix, pH 7, Naxo OÜ, Estonia), fruitbody pieces were crushed with a sterile scalpel and vortexed for $5 \mathrm{~min}$ at maximum speed to isolate tightly adhering bacteria from the hyphal surface. Using a Drigalski spatula, $100 \mu \mathrm{l}$ of the homogenate was plated to one Petri dish with R2A low nutrient agar or in some cases onto twice diluted tryptic soybean agar (TSA, Liofilchem, Italy). Both media have successfully been used for isolation of bacteria from fungal fruitbodies or from lichen thalli (e.g., Dahm et al., 2005; Grube et al., 2009). The plates were incubated at $25^{\circ} \mathrm{C}$ for 30 days not to miss the slowgrowing bacteria. From each Petri dish, colonies with a different size, shape, elevation, color, margin, texture, surface, or opacity were transferred to a new Petri dish with TSA. Most of the isolates were examined using the light microscope to record their Gram reaction and cell shape. Reinoculation was repeated until pure isolates were obtained. Cultures were preserved at $-80^{\circ} \mathrm{C}$ in $50 \%$ glycerol in the Tartu Fungal Culture Collection (TFC).

\section{DNA Extraction}

\section{Culture Strains}

Bacteria from 2-4 days old colonies of each isolate on TSA were transferred into $100 \mu \mathrm{l}$ of lysis buffer containing $0.8 \mathrm{M}$ Tris- $\mathrm{HCl}$, $0.2 \mathrm{M}\left(\mathrm{NH}_{4}\right)_{2} \mathrm{SO}_{4}, 0.2 \% \mathrm{w} / \mathrm{v}$ Tween-20 (10× Reaction Buffer $\mathrm{B}$, Solis Biodyne, Tartu, Estonia), and $2.5 \mu \mathrm{l}$ of proteinase $\mathrm{K}$ $(20 \mathrm{mg} / \mathrm{ml}$, Fermentas, Lithuania). The probes were incubated at $56^{\circ} \mathrm{C}$ for $15-16 \mathrm{~h}$, followed by incubation at $98^{\circ} \mathrm{C}$ for $15 \mathrm{~min}$ to inactivate proteinase K. From each probe, $16 \mathrm{~S}$ rRNA gene was amplified using the universal bacterial primers $27 \mathrm{f}$ and $1492 \mathrm{r}$ under the following PCR conditions: $95^{\circ} \mathrm{C}$ for $15 \mathrm{~min}, 30$ cycles of $95^{\circ} \mathrm{C}$ for $30 \mathrm{~s}, 58^{\circ} \mathrm{C}$ for $30 \mathrm{~s}$, and $72^{\circ} \mathrm{C}$ for $1 \mathrm{~min}$ and the final elongation step at $72^{\circ} \mathrm{C}$ for $10 \mathrm{~min}$. The $25 \mu \mathrm{l} \mathrm{PCR}$ mix consisted of $5 \mu \mathrm{l}$ of $5 \times$ HOT FIREPol Blend MasterMix (Solis Biodyne, Tartu, Estonia), $1 \mu \mathrm{l}$ of 10 -fold diluted DNA extract, $0.5 \mu \mathrm{l}$ of each primer $(200 \mathrm{nM})$ and $18 \mu \mathrm{l}$ of sterilized $\mathrm{H}_{2} \mathrm{O}$. The PCR products were visualized on $1 \%$ agarose gel and purified using ExoSAP-IT (USB Corporation, Cleveland, $\mathrm{OH}$, USA). Purified PCR products were sequenced using the Sanger method at the Macrogen Inc. (Amsterdam). Sequences obtained from all isolates have been uploaded to GenBank, with accession numbers KY681818-KY682069 (Supplementary Table S3).

\section{High-Throughput Sequencing}

The frozen fruitbody pieces were crushed for $3 \mathrm{~min}$ in $200 \mu \mathrm{l}$ of phosphate-buffered saline water solution (PBS) $(0.15 \mathrm{M} \mathrm{NaCl}$ $10 \mathrm{mM}$ phosphate buffer, $\mathrm{pH}$ 7.4) using $3.2 \mathrm{~mm}$ diameter metal beads followed by centrifuging the homogenate at $3,000 \times g$ for $30 \mathrm{~s}$. DNA was extracted from the supernatant using the High Pure PCR Template Preparation Kit (Roche Applied Science, Mannheim, Germany) following the manufacturer's instructions for isolation of bacteria. PowerMax Soil DNA Isolation Kit 
(MoBio, Carlsbad, CA, USA) was used for the extraction of DNA from soil following the manufacturer's instructions.

The variable $\mathrm{V} 3-\mathrm{V} 4$ regions of $16 \mathrm{~S}$ rDNA gene were amplified using the bacterial primers 515F (5'-GTGYC AGCMGCCGCGGTAA-3') and 806R (5'-GGACTACNVGGGT WTCTAAT- $\left.3^{\prime}\right)$. The $25 \mu \mathrm{l}$ of PCR mix consisted of $16 \mu \mathrm{l}$ of sterilized $\mathrm{H}_{2} \mathrm{O}, 5 \mu \mathrm{l}$ of $5 \times$ HOT FIREPol Blend MasterMix (Solis Biodyne, Tartu, Estonia), $0.5 \mu \mathrm{l}$ of each primer (200 nM), and $3 \mu \mathrm{l}$ of the DNA extract. Amplifications were performed using the following PCR conditions: $95^{\circ} \mathrm{C}$ for $15 \mathrm{~min}$, followed by $25-30$ cycles of $95^{\circ} \mathrm{C}$ for $30 \mathrm{~s}, 50^{\circ} \mathrm{C} 45 \mathrm{~s}$, and $72^{\circ} \mathrm{C}$ for $1 \mathrm{~min}$ with a final extension step at $72^{\circ} \mathrm{C}$ for $10 \mathrm{~min}$. The PCR products were visualized on $1 \%$ agarose gel. For DNA samples in which no PCR product could be amplified, up to 35 PCR cycles were applied (Supplementary Table S4). The PCR products were sequenced at the Estonian Biocentre (Tartu, Estonia) using Illumina MiSeq technology. Representative sequence from each operational taxonomic unit (OTU) was submitted to GenBank and can be retrieved from BioProject PRJNA379722: Fungal bacteria.

\section{Sequence Analysis}

The sequences obtained from culture isolates were assembled and manually edited using Sequencher 5.1 (Gene Codes Corporation, USA) and subsequently aligned using MAFFT $^{1}$. The program AliView (Larsson, 2014) was used to trim the nearly fulllength $16 \mathrm{~S}$ rRNA sequences to correspond to the positions 56-1,461 in E. coli or to positions $323-1,461$ in case only the reverse primer was used for sequencing. Sequence similarity searches were performed using SILVA ${ }^{2}$, nucleotide-nucleotide basic local alignment search tool (BLASTn) in GenBank and the GreenGenes database ${ }^{3}$.

Illumina sequences from soil and fungal samples, 906,778 raw reads in total, were processed using the software package LotuS (Hildebrand et al., 2014). The primer and barcode region were removed from each read and sequences shorter than 170 nucleotides or those detected as chimeric excluded. The remaining reads, $247 \mathrm{bp}$ in length, were clustered into OTUs with UPARSE based on $97 \%$ sequence similarity threshold. OTUs that occurred in high numbers in negative controls (52,325 reads) and those with affinities in eukaryotes (250,268 reads), Archaea (79 reads), or of unknown origin (152,631 reads), accounting for $57 \%$ of quality-filtered sequences, were discarded, resulting in 247,125 quality-passed reads from 955 bacterial OTUs, on average 1,765 reads per sample. Seventy-six OTUs (754 reads), each represented only in one sample, as well as OTUs with less than five reads in total, were excluded from downstream analyses. Representative sequences from each bacterial OTU were classified using the SILVA database and compared with most similar sequences in GenBank, $\mathrm{RDP}^{4}$ and in GreenGenes databases. The final taxonomy was determined based on the best blast match for a given representative sequence in any of the above databases. Their affinities at the species, genus,

\footnotetext{
${ }^{1}$ http://mafft.cbrc.jp/alignment/server/index.html

${ }^{2}$ https://www.arb-silva.de

${ }^{3}$ http://greengenes.lbl.gov

${ }^{4}$ http://rdp.cme.msu.edu/
}

family, order, class, and phylum level were assigned applying the sequence similarity thresholds of 97, 94.5, 86.5, 82.0, 78.5, and 75.0\%, respectively (Yarza et al., 2014).

For OTU-level comparison of HTS-detected bacteria with those isolated into culture, the $\mathrm{V} 3-\mathrm{V} 4$ regions were extracted from the full-length $16 \mathrm{~S}$ rDNA sequences from the latter using the program AliView. These spanned from positions 534 to 781 in E. coli, corresponding to the same 247 bp stretch obtained with HTS and were clustered with quality-filtered Illumina sequences using cd-hit-est at $97 \%$ sequence similarity in the program CDHIT (Huang et al., 2010). For analyzing together HTS and Sanger sequencing data from fruitbodies, these from each fungal species at a particular site were pooled and transformed into the presence/absence form. The relative abundance of bacterial taxa in fruitbodies was calculated separately in case of the datasets obtained from Sanger sequencing of culture isolates and from HTS of fungal tissues. For each fungal taxon, the abundance of individual bacterial groups was calculated as the proportion of infested fruitbodies among sampled ones or as the relative proportion of sequence reads in a particular fungal taxon, respectively. For calculating the relative abundance of bacterial taxa in soil, the read number of each bacterial taxon was divided by the total number of reads detected from the 12 samples. The soil data was not rarefied as it was not included in any of the statistical analyses conducted only with fruitbody data.

\section{Statistical Analysis}

In the final HTS based bacterial OTU community table, sequence counts of all fruitbodies of one fungal species at one site were merged into one sample. Three samples with $<12$ sequences were excluded from statistical analyses, leaving 64 for downstream analyses. Because the total read numbers differed substantially, 49 samples with $>100$ reads were rarefied to 100 reads per sample and merged with rest of the samples. The resulting OTU table was further normalized using Hellinger transformation, and OTUs represented by a single sequence (singletons) were excluded from data analysis. The vegan package in R (vers.3.2.2, R Development Inc., 2013) was used for all these procedures.

Permutational analysis of variation (PERMANOVA) was performed using Adonis function to determine the effect of sample site, habitat type, soil type, fungal host identity, and soil parameters on bacterial community composition in fungal fruitbodies. The best model was selected based on forward selection with $F$-value as the selection criterion. Canonical analysis of principal (CAP) coordinates, based on Bray-Curtis dissimilarity (Anderson and Willis, 2003), was applied to visualize differences in bacterial communities among fungal taxa at three taxonomic levels (order, genus, species) and to visualize the effect of soil parameters underlying the observed variation based on Illumina data. CAP was performed using the program Primer 6 (Primer-E Ltd., Plymouth, UK) with the PERMANOVA+ add-on package. The function betadisper in the vegan package was used for analysis of homogeneity of groups dispersions followed by Tukey's honestly significant difference (HSD) tests. The program EstimateS 9.1.0 (Colwell et al., 2012) was used for finding the estimators for Coleman rarefaction curves. 


\section{RESULTS}

\section{Structure of Bacterial Communities in Mushrooms}

Bacterial colonies were successfully isolated from 177 (out of 221) fruitbodies used for inoculation on agar media. In total, 252 bacterial strains were isolated after reinoculation of different colonies from each original Petri dish (Supplementary Table S3). Most of these bacteria were Gram-negative rods, except for two Gram-positive cocci (Staphylococcus pasteuri and Staphylococcus epidermidis), and two Gram-positive rods (Microbacterium aurum and Frondicola australicus). Based on full-length $16 \mathrm{~S}$ rDNA sequences, the isolated bacteria were identified as belonging to 4 phyla, 7 classes, 10 orders, 13 families, 17 genera, and 54 species, whereas no names could be assigned to some isolates at the genus or species level (Supplementary Table S3). Clustering that applied 97 or 98.6\% similarity threshold revealed 37 and 58 species-level groups, respectively. The phylum Proteobacteria (present in 97\% of fruitbodies) and its two classes, Gammaproteobacteria and Betaproteobacteria, were the dominant taxa among the isolates (Supplementary Table S5 and Figures 1A,B). At lower taxonomic levels, the families Burkholderiaceae (found in $42 \%$ of fruitbodies), Pseudomonadaceae (36\%), Enterobacteriaceae (33\%), and respective orders were most common. The most abundant genera, Pseudomonas and Burkholderia, included Pseudomonas fluorescens and Pseudomonas brenneri (both in 14\% of fruitbodies); Burkholderia phytofirmans (in 10\%), Burkholderia phenazinium (8\%), Burkholderia xenovorans (6\%), Burkholderia bryophila (6\%), and Burkholderia graminis (5\%). Other bacterial taxa, at all six taxonomic levels, grew out in culture from less than $5 \%$ of fruitbodies. With respect to host taxa, different bacterial groups often dominated among isolates obtained from different fungal genera (Supplementary Table S5). For example, Pseudomonas was the most common bacterial genus isolated from Cantharellus and Amanita but least frequent in the three genera of Boletaceae, from which Enterobacteriaceae/-les were most frequently isolated.

HTS detected 179,964 bacterial reads from 178 mushroom fruitbodies, on average 2,812 reads per the 64 pooled samples. These sequences clustered into 446 bacterial OTUs that belonged to 24 (including five unclassified) bacterial phyla, 44 (11 unclassified) classes, 99 (32 unclassified) orders, 157 (53 unclassified) families, and 306 (153 unclassified) genera (Supplementary Tables S6, S7). Proteobacteria was the most abundant phylum in all fungal genera, except for Cantharellus, where Bacteroidetes was of equal abundance (Supplementary Table S5 and Figure S1). The identity and relative abundance of the five main bacterial OTUs was considerably different among mushroom species (Figure 2). A Pseudomonas (OTU 147) was common in all three Agaricales and three boletes, whereas two species of Burkholderia, OTUs 59c and 2c, dominated in three boletes or in Lactarius rufus, respectively. Cortinarius caperatus and Russula decolorans shared their dominant, Enhydrobacter sp. (OTU 209), whereas Cantharellus cibarius, with the most distinct bacterial community, had only Pedobacter sp. (OTU 1399) in common with $C$. caperatus.
The 97\% similarity-based clustering of V3-V4 regions of $16 \mathrm{~S}$ sequences obtained from isolates distinguished 25 OTUs, eight of which were not detected with HTS. Although infrequent, two of such OTUs represented also unique genera (Plantibacter and Flavobacterium) in our dataset. All bacterial families and higher level taxa observed in culture were also detected by HTS. However, Enterobacteriales, Pseudomonadales, and Burkholderiales were poorly represented among HTS reads, yet isolated from over one third of the fruitbodies (Supplementary Table S5). By contrast, Alphaproteobacteria and Sphingobacteriia/Bacteroidetes were abundant in the HTS dataset (Figures 1A,B) but rare or undetected in culture.

\section{Comparison of Bacterial Communities in Fungal Fruitbodies and in Soil}

HTS from the 12 soil samples detected 66,407 quality-filtered reads that clustered into 639 OTUs belonging to 24 (including five unclassified) bacterial phyla, 51 (21 unclassified) classes, 93 (43 unclassified) orders, 160 (90 unclassified) families, and 406 (314 unclassified) genera (Supplementary Table S8). Rarefaction curves showed that the number of bacterial OTUs with increasing number of reads reached a plateau in case of mushrooms but not in soil bacteria (Supplementary Figure S2). In general, $21.6 \%$ of all bacterial OTUs detected by HTS from mushrooms and soil were shared (Supplementary Figure S3), while 31\% of the OTUs in soil also occurred in fruitbodies and $41 \%$ of fruitbody OTUs were present in soil. Although most of the commonly observed bacterial taxa occurred both in mushrooms and in soil, their relative abundance often differed significantly between these two habitats. Namely, Proteobacteria was the most abundant phylum both in fruitbodies and in soil, whereas it was followed by Bacteroidetes in fruitbodies, but Acidobacteria and Actinobacteria in soil samples (Figure 1A). At the class level, Acidobacteriia was most abundant in soil and Sphingobacteriia in mushrooms, followed by Alphaproteobacteria in both (Figure 1B and Supplementary Figure S4). The structure of bacterial communities in these two environments differed also at the bacterial order level (Figure 3). Bacterial taxa detected only from mushrooms included three phyla (Candidatus Saccharibacteria, Deinococcus-Thermus, and Candidate division OP3), eight classes and 24 orders (Supplementary Tables S6, S7). By contrast, three phyla, two classes, and 18 orders were found only from soil (Supplementary Tables S6, S8).

\section{Factors Affecting the Structure of Mushroom-Associated Bacterial Communities}

Soil $\mathrm{pH}, \delta 15 \mathrm{~N}$, fungal order, and genus were the best determinants of the bacterial community composition in fungal fruitbodies based on PERMANOVA analysis (Table 2 and Supplementary Table S9). Similar results were obtained when using the presence/absence matrix of merged culture and HTS data (Supplementary Table S10). The effect of host identity and soil $\mathrm{pH}$ appeared to be independent (Table 2 and Supplementary Table S11). CAP analysis separated the four fungal orders (Supplementary Figure S5), eight genera 


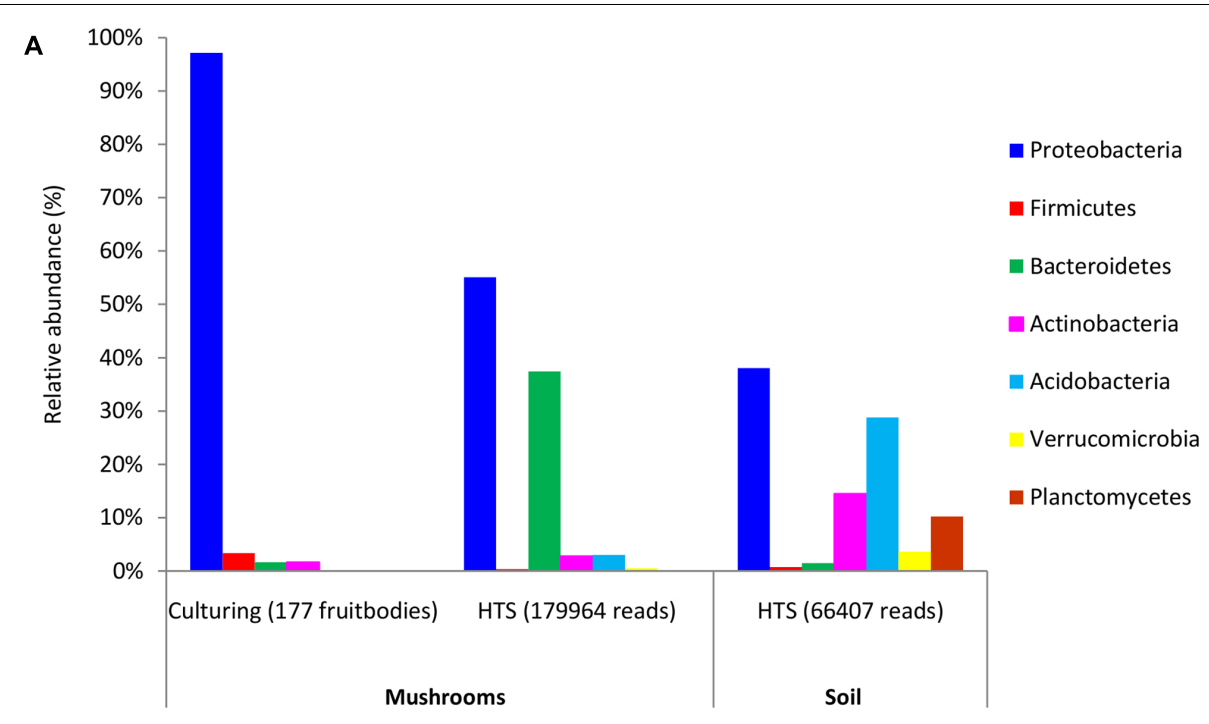

B

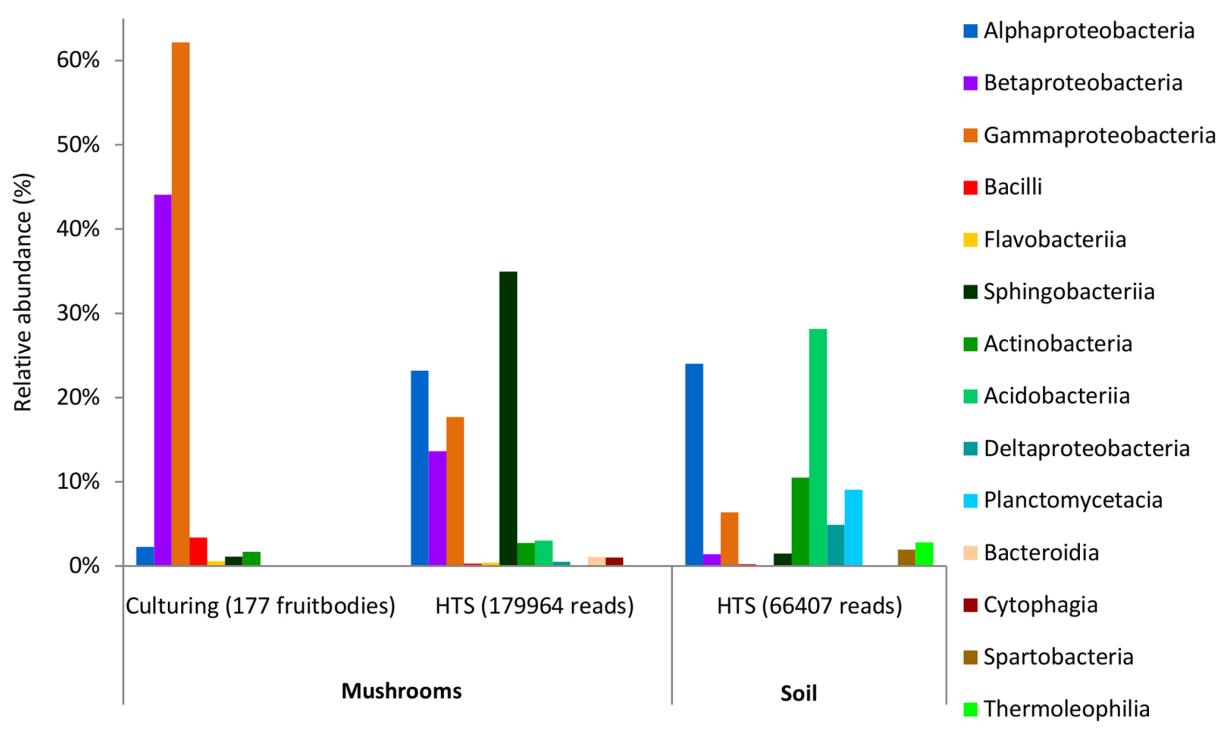

FIGURE 1 | Relative abundance of dominant bacterial phyla (A) and classes (B) in mushrooms based on culturing and high-throughput sequencing (HTS), and in soil based on HTS. The ratios show the share of fruitbodies inhabited by the bacterial taxon or of lllumina read numbers from that of the total (in parentheses) for culture isolates and HTS data, respectively.

(Figure 4), and 14 species (Supplementary Figure S6) with respect to their bacterial communities along the second axis of CAP, mainly correlated to $\mathrm{pH}$ and some other soil variables. The CAP plot revealed lower intraspecific variation of the distinct bacterial communities in C. cibarius compared to that in other mushroom species with largely overlapping bacterial community composition (Supplementary Figure S6). The same pattern was distinguished at higher fungal taxonomic levels, with bacterial communities of Cantharellus and Cantharellales being most distinct from those of other fungal taxa. The Tukey's test confirmed the distinctness of bacterial communities in Cantharellales by revealing significant differences $(p<0.05)$ in bacterial community composition between all pairs of orders that involved Cantharellales (C): C-Agaricales, C-Boletales and C-Russulales (Supplementary Figure S7).

\section{DISCUSSION}

\section{Determinants of Bacterial Communities in Mushrooms}

This study presents the first comprehensive analysis of the structure of bacterial communities in forest mushrooms. We found that bacterial communities across the eight studied mushroom genera were primarily affected by soil $\mathrm{pH}$ - the main determinant of bacterial diversity and community composition 


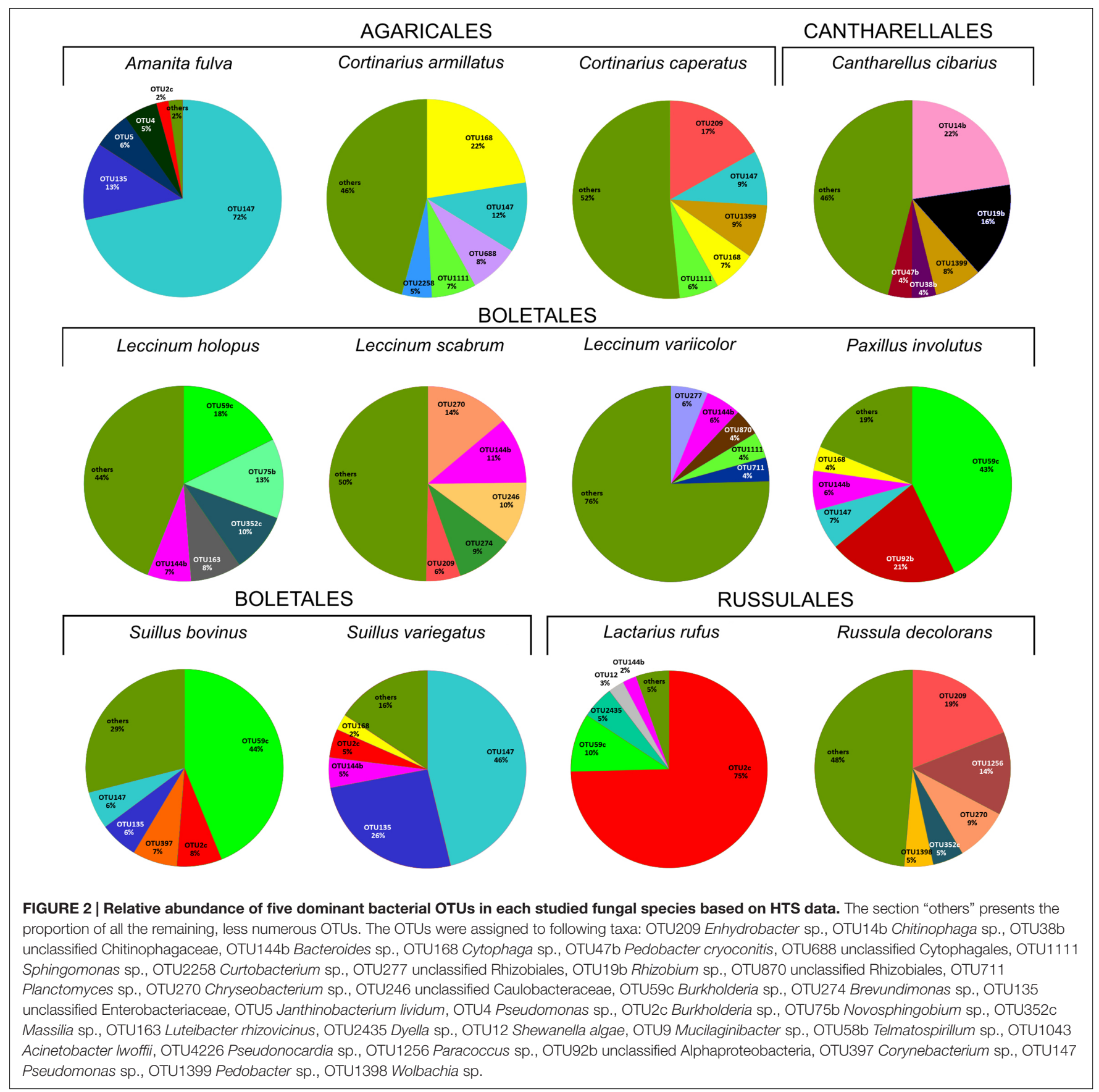

in soil (Fierer and Jackson, 2006; Lauber et al., 2009; Rousk et al., 2010). This effect was likely mediated by the indirect impact of soil $\mathrm{pH}$ on surrounding soil bacterial communities that appeared to provide a substantial part of bacteria in mushrooms. Although Proteobacteria dominated on both habitats, contrasting structure of bacterial communities was observed in soil and fungal fruitbodies, from which $41 \%$ of OTUs were also detected from adjacent soil samples. However, part of these community differences probably resulted from the different time and methodology used for sampling and handling soil and fruitbodies.
Compared to the effect of soil $\mathrm{pH}$, the effect of fungal identity on the structure of bacterial communities in mushrooms was secondary but significant. In particular, we found that fungal taxonomy at the genus and order level significantly determines bacterial community structure in mushrooms. These results point to some level of habitat specificity and possibly specific functions of certain bacteria depending on the taxonomy and lifestyle of mushrooms. Indeed, a strong selection of specific bacterial communities has been observed in the ectomycorrhizosphere of truffles and other EcM fungi (Marupakula et al., 2015; Deveau et al., 2016). Similar to what has been observed 
A

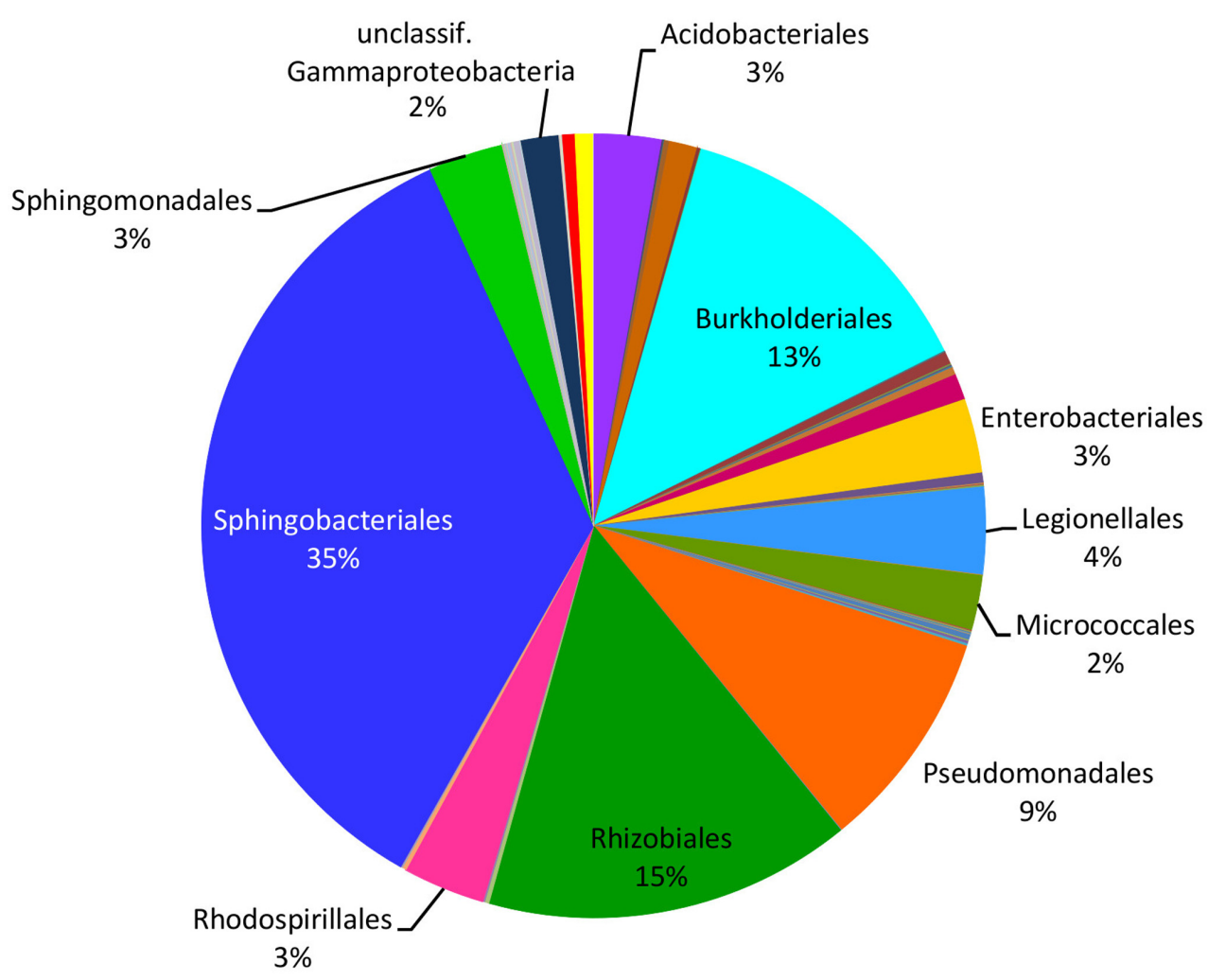

$\mathbf{B}$

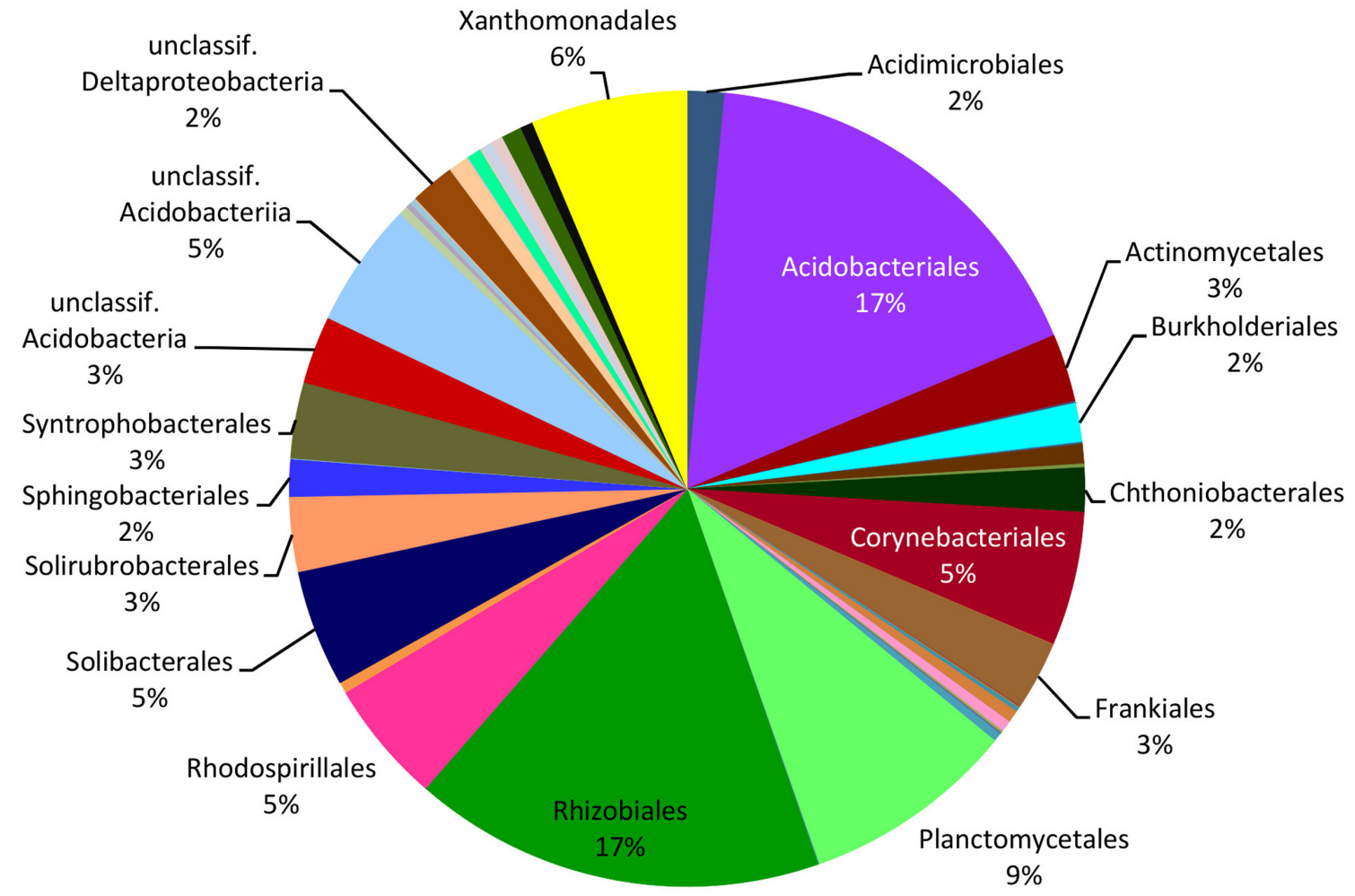

FIGURE 3 | Relative distribution of the bacterial orders in mushrooms (A) and in soil (B) based on the read numbers normalized by the total number of reads from HTS data. Names of the taxa are presented only for bacterial groups with abundance $\geq 2 \%$. 
TABLE 2 | Effect of soil variables and host identity on bacterial community composition in fungal fruitbodies as revealed by PERMANOVA of rarefied, Hellinger transformed HTS read numbers.

\begin{tabular}{lcccccc}
\hline & Df & SS & MS & $\boldsymbol{F}$ & $\boldsymbol{R}^{\mathbf{2}}$ & $\boldsymbol{R}^{\mathbf{2}}$ adjusted \\
\hline Soil pH & 1 & 1.9065 & 1.90646 & 6.2427 & 0.07690 & 0.0620 \\
Fungal order & 3 & 3.3701 & 1.12338 & 3.6785 & 0.13594 & 0.0927 \\
Soil $815 \mathrm{~N}$ & 1 & 0.7247 & 0.72472 & 2.3731 & 0.02923 & 0.001 \\
Fungal genus & 4 & 2.2984 & 0.57461 & 1.8816 & 0.09271 & 0.001 \\
Residuals & 54 & 16.4910 & 0.30539 & & 0.66521 & 0.0312 \\
Total & 63 & 24.7907 & & & 1 & -1.34353 \\
\hline
\end{tabular}

$p$-value is based on 999 permutations.
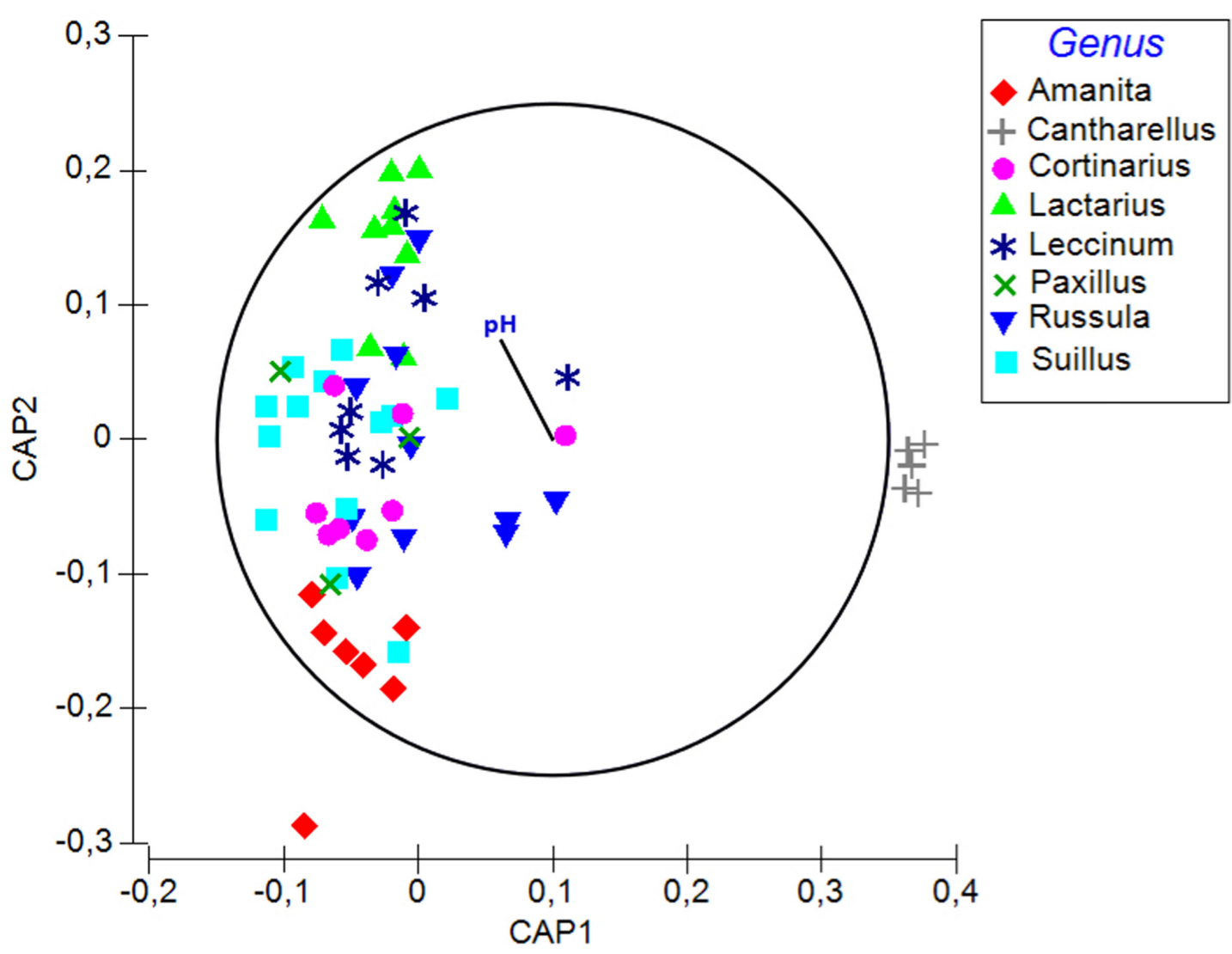

FIGURE 4 | A plot of the canonical analysis of principal (CAP) coordinates visualizing the differences in bacterial communities among fungal genera and the effect of soil parameters underlying the observed variation based on Bray-Curtis dissimilarity of HTS data. Vector shows Pearson correlations with soil $\mathrm{pH}$ along the second axis of CAP (variables with correlations $\geq 0.3$ presented). Correlation coefficient for $\mathrm{pH}$ is -0.26 .

in plants (Bulgarelli et al., 2013; Vandenkoornhuyse et al., 2015), variation of mushroom carbon-compounds or differential carbon allocation across different fungal groups (Boersma et al., 2009, 2010; Warmink et al., 2009) may mediate bacterialfungus associations. For example, the difference in bacterial communities in mycorrhizae formed by Suillus bovinus and Paxillus involutus were ascribed to the preference of either mannitol or fructose, produced in the mycorrhizosphere of respective fungi (Timonen et al., 1998). Similarly, glycerol released by Laccaria proxima attracts Variovorax paradoxuslike bacteria in the mycosphere (Boersma et al., 2010). The initial selection of bacteria probably depends on soil, especially the mycosphere properties (Warmink et al., 2009), whereas the second step may be determined by fruitbody characteristics, such as the presence of different metabolites, compounds, $\mathrm{pH}$ (Danell et al., 1993), etc. In both fungal structures, bacteria exploit fungal exudates on hyphal surface, leaving fungal cells intact (Danell, 1994; Timonen et al., 1998). The exudation of fungal C-compounds, in turn, has been found to depend on environmental conditions, considerably decreasing at lower $\mathrm{pH}$ and temperature (Rangel-Castro and Danell, 2002), which may affect bacterial groups that depend on these 
compounds. Also in case of arbuscular mycorrhizal fungi, exudates from their spores have been suggested to explain the key role of the identity of these fungi in shaping the microbial community surrounding their spores (Iffis et al., 2016).

\section{Distinctness of Fungal-Associated Bacterial Communities}

Our results add new evidence to support the notion of the common occurrence of selected bacterial taxa in different structures formed by fungi. Dominant bacteria detected here in mushrooms suggest that similarly to the ectomycorrhizosphere (Burke et al., 2008; Uroz et al., 2012; Deveau et al., 2016), EcM fungi tend to share a core bacterial community in their fruitbodies. Among the latter, based on HTS, the most evident common trend in bacterial communities of truffles (AntonyBabu et al., 2014; Benucci and Bonito, 2016) and mushrooms is the high abundance of Proteobacteria and Bacteroidetes, but the exclusion/paucity of Acidobacteria, Actinobacteria, and Planctomycetes, despite their abundance in the soils of all sampling localities. Low abundance of some of these taxa, as well as Flavobacteria, Firmicutes, or Verrucomicrobia in fruitbodies is shared with EcM formed by different fungi (Vik et al., 2013; Deveau et al., 2016). Differences between soil and fungal-associated bacterial communities may be related to lower nutritional status of soil compared to the so called hot spots created by fungal hyphae in soil (Nazir et al., 2010). It has been shown that the abundance of Proteobacteria is stimulated by higher nutritional status of soil in contrast to, e.g., Acidobacteria which prefer low-nutrient soils (Torsvik and Øvreås, 2002). Thus it is likely that the dominance of Proteobacteria in hyphae (Cho et al., 2003), fruitbodies (Barbieri et al., 2005; Dahm et al., 2005; Zagriadskaia et al., 2013), and mycorrhizal roots (Poole et al., 2001; Frey-Klett et al., 2007) is due to elevated carbon content in these fungal habitats.

Despite the dominance of Proteobacteria in fungus-associated bacterial communities, there seems to be substantial variation among its inclusive lower level and some other bacterial groups, relating to the identity, structure or lifestyle of the fungal host. For example, Alphaproteobacteria (mostly Bradyrhizobiaceae) dominated in fruitbodies of various Tuber species (Antony-Babu et al., 2014; Benucci and Bonito, 2016) and EcM of several fungi (Kataoka et al., 2008; Uroz et al., 2012; Deveau et al., 2016) but was not abundant in studied mushrooms, in Tuber aestivum EcM (Gryndler et al., 2013) or in other truffle genera (Benucci and Bonito, 2016). By contrast, Pseudomonas was one of the most common genera in mushrooms studied by us and earlier authors (Dahm et al., 2005) as well as in the casing layer of cultivated Agaricus bisporus (Zaranejad et al., 2012) but has been reported to be absent or very rare in truffles (Antony-Babu et al., 2014; Benucci and Bonito, 2016). Members of Burkholderia, frequently found in mycorrhizae (Timonen et al., 1998; Sbrana et al., 2002), appeared to be especially affiliated to Lactarius. Namely, these were by far the most abundant bacteria in fruitbodies of $L$. rufus, as evidenced here, but also common in EcM formed by L. rufus and Pinus sylvestris (Poole et al., 2001). Rhizobium and Chitinophaga fit the category of "specific fungiphiles" (Warmink et al., 2009) occurring almost exclusively in Cantharellus.

The effect of host identity on the structure of bacterial communities, revealed in this study, was largely (but not exclusively) driven by the distinct bacterial composition in fruitbodies of C. cibarius. The chanterelle belongs to the order Cantharellales that represents one of the early-diverged lineages of Agaricomycetes. It is thus phylogenetically most distant among mushroom-forming basidiomycetes, which is also reflected in the physiology and key compounds produced by members of this order (Rangel-Castro and Danell, 2002). Besides the high concentration of ergocalciferol (Rangel-Castro et al., 2002b) and accumulation of some metals from the soil (Drewnowska and Falandysz, 2015), fruitbodies of $C$. cibarius are known to produce antimicrobial compounds (Aina et al., 2012) that suppress the growth of some bacterial species (Barros et al., 2008). The distinct chemistry may explain the unique bacterial community of C. cibarius, which unlike other mushrooms, was dominated by members of the phylum Bacteroidetes (Supplementary Table S3). It is tempting to hypothesize that certain bacteria enriched in antibiotic resistance genes may be able to thrive in chanterelles.

\section{Methodological Considerations for Detection of Bacteria}

Our results advocate the combined use of HTS and culturing in characterizing bacterial communities, in line with studies revealing differences in microbial diversity detected by the two methods in different environments (Vaz-Moreira et al., 2011; Stefani et al., 2015). While HTS by far surpasses culturing in revealing bacterial diversity, the latter can detect certain taxa missed by the former method and allow more precise identification of bacterial taxonomic and functional diversity. Consistent method-driven discrepancies can be discerned in revealing the structure of the bacterial communities of the studied epigeious basidiomycetes and hypogeous ascomycetes available for comparison, despite their different taxonomic identity and lifestyle. In particular, Gammaproteobacteria dominate among bacterial cultures from studied mushrooms as well as truffles but are much less frequently detected by culture-independent methods (Barbieri et al., 2005, 2007). By contrast, the latter revealed that Alphaproteobacteria occurred in mushrooms in this study, in truffles (Antony-Babu et al., 2014; Benucci and Bonito, 2016) and in truffle-like ascomycetes (Quandt et al., 2015), despite being absent or rarely isolated in culture. Similar to what has been reported for truffles, we detected Actinobacteria with similar frequency based on both methods, whereas members of Firmicutes were common in culture but rare in HTS data.

Evidence presented here suggests the potential of HTS in contrast with culture-based methods to capture differences among bacterial communities of different host taxa and the effect of underlying factors shaping their 
structure. The best example was provided by the bacterial community of the chanterelle that was clearly distinct from those of other mushrooms based on the dominance of Chitinophagaceae/Sphingobacteriales/Bacteroidetes in the HTS data. However, culturing revealed that these taxa were rare in all mushrooms, bacterial isolates of which, including C. cibarius, were dominated by Gammaproteobacteria.

\section{CONCLUSIONS}

This study presents the first assessment of the structure of bacterial communities in mushrooms using HTS methods. Our findings support the hypothesis that bacterial communities in mushrooms are to a large extent affected by the same abiotic factors that shape bacterial communities in the surrounding soil, which is likely a major source of bacteria in mushrooms. Nevertheless, we found a significant and strong effect of fungal identity on the structure of their bacterial communities. This suggests that at least some bacteria may have specific symbiotic functions in different groups of mushrooms. In addition, conditions provided in fruitbodies may differ among fungal groups, resulting in habitat filtering of certain bacterial groups. Further studies are needed to explicitly test these hypotheses.

\section{AUTHOR CONTRIBUTIONS}

MP participated in study design, in collecting samples, in conducting molecular and statistical analyses, and in writing

\section{REFERENCES}

Aina, D. A., Jonathan, S. G., Olawuyi, O. J., Ojelabi, D. O., and Durowoju, B. M. (2012). Antioxidant, antimicrobial and phytochemical properties of alcoholic extracts of Cantharellus cibarius - a Nigerian mushroom. N. Y. Sci. J. 5, 114-120.

Anderson, M. J., and Willis, T. J. (2003). Canonical analysis of principal coordinates: a useful method of constrained ordination for ecology. Ecology 84, 511-525. doi: 10.1890/0012-9658(2003)084[0511:CAOPCA]2.0.CO;2

Antony-Babu, S., Deveau, A., Van Nostrand, J. D., Zhou, J., Le Tacon, F., Robin, C., et al. (2014). Black truffle-associated bacterial communities during the development and maturation of Tuber melanosporum ascocarps and putative functional roles. Environ. Microbiol. 16, 2831-2847. doi: 10.1111/14622920.12294

Bäckhed, F., Ley, R. E., Sonnenburg, J. L., Peterson, D. A., and Gordon, J. I. (2005). Host-bacterial mutualism in the human intestine. Science 307, 1915-1920. doi: 10.1126/science.1104816

Bandara, W. M. M. S., Seneviratne, G., and Kulasooriya, S. A. (2006). Interactions among endophytic bacteria and fungi: effects and potentials. J. Biosci. 31, 645-650. doi: 10.1007/BF02708417

Barbieri, E., Bertini, L., Rossi, I., Ceccaroli, P., Saltarelli, R., Guidi, C., et al. (2005). New evidence for bacterial diversity in the ascoma of the ectomycorrhizal fungus Tuber borchii Vittad. FEMS Microbiol. Lett. 247, 23-35. doi: 10.1016/j. femsle.2005.04.027

Barbieri, E., Ceccaroli, P., Saltarelli, R., Guidi, C., Potenza, L., Basaglia, M., et al. (2010). New evidence for nitrogen fixation within the Italian white truffle Tuber magnatum. Fungal Biol. 114, 936-942. doi: 10.1016/j.funbio.2010.09.001

Barbieri, E., Guidi, C., Bertaux, J., Frey-Klett, P., Garbaye, J., Ceccaroli, P., et al. (2007). Occurrence and diversity of bacterial communities in Tuber magnatum during truffle maturation. Environ. Microbiol. 9, 2234-2246. doi: 10.1111/j. 1462-2920.2007.01338.x the manuscript. KP participated in study design, in collecting samples, in conducting molecular analyses, and in writing the manuscript. $\mathrm{MB}$ participated in study design, conducting statistical analyses, and in writing the manuscript.

\section{FUNDING}

This study was funded by the Estonian Science Foundation (grants PUT1317, IUT20-30) and the European Union through the European Regional Development Fund (the Center of Excellence EcolChange).

\section{ACKNOWLEDGMENTS}

We would like to thank Indrek Hiiesalu for contributing soil samples and associated metadata, Rasmus Puusepp for laboratory assistance, and Paula Ann Kivistik from the Estonian Genome Centre for providing advice with respect to Illumina MiSeq sequencing. Tanel Tenson and Viia Kõiv (Technology Institute of the University of Tartu) are acknowledged for suggestions to improve the manuscript.

\section{SUPPLEMENTARY MATERIAL}

The Supplementary Material for this article can be found online at: http://journal.frontiersin.org/article/10.3389/fmicb. 2017.00836/full\#supplementary-material

Barros, L., Venturini, B. A., Baptista, P., Estevinho, L. M., and Ferreira, C. F. R. (2008). Chemical composition and biological properties of portuguese wild mushrooms: a comprehensive study. J. Agric. Food Chem. 56, 3856-3862. doi: $10.1021 /$ jf 8003114

Benucci, G. M. N., and Bonito, G. M. (2016). The truffle microbiome: species and geography effects on bacteria associated with fruiting bodies of hypogeous pezizales. Microb. Ecol. 72, 4-8. doi: 10.1007/s00248-016-0755-3

Boersma, F. G. H., Otten, R., Warmink, J. A., Nazir, R., and Van Elsas, J. D. (2010). Selection of Variovorax paradoxus-like bacteria in the mycosphere and the role of fungal-released compounds. Soil Biol. Biochem. 42, 2137-2145. doi: 10.1016/j.soilbio.2010.08.009

Boersma, F. G. H., Warmink, J. A., Andreote, F. A., and Van Elsas, J. D. (2009). Selection of Sphingomonadaceae at the base of Laccaria proxima and Russula exalbicans fruiting bodies. Appl. Environ. Microbiol. 75, 1979-1989. doi: 10.1128/AEM.02489-08

Bulgarelli, D., Schlaeppi, K., Spaepen, S., Van Themaat, E., Ver, L., and SchulzeLefert, P. (2013). Structure and functions of the bacterial microbiota of plants. Annu. Rev. Plant. Biol. 64, 807-838. doi: 10.1146/annurev-arplant-050312120106

Burke, D. J., Dunham, S. M., and Kretzer, A. M. (2008). Molecular analysis of bacterial communities associated with the roots of Douglas fir (Pseudotsuga menziesii) colonized by different ectomycorrhizal fungi. FEMS Microbiol. Ecol. 65, 299-309. doi: 10.1111/j.1574-6941.2008.00491.x

Cho, Y.-S., Kim, J.-S., Crowley, D. E., and Cho, B.-G. (2003). Growth promotion of the edible fungus Pleurotus ostreatus by fluorescent pseudomonads. FEMS Microbiol. Lett. 218, 271-276. doi: 10.1016/S0378-1097(02)01144-8

Citterio, B., Malatesta, M., Battistelli, S., Marcheggiani, F., Baffone, W., Saltarelli, R., et al. (2001). Possible involvement of Pseudomonas fluorescens and Bacillaceae in structural modifications of Tuber borchii fruit bodies. Can. J. Microbiol. 47, 264-268. doi: 10.1139/cjm-47-3-264 
Colwell, R. K., Chao, A., Gotelli, N. J., Lin, S. Y., Mao, C. X., Chazdon, R. L., et al. (2012). Models and estimators linking individual-based and sample-based rarefaction, extrapolation, and comparison of assemblages. J. Plant Ecol. 5, 3-21. doi: 10.1093/jpe/rtr044

Dahm, H., Wrótniak, W., Strzelczyk, E., and Bednarska, E. (2005). Diversity of culturable bacteria associated with fruiting bodies of ectomycorrhizal fungi. Phytopathol. Pol. 38, 51-62.

Danell, E. (1994). Cantharellus cibarius: Mycorrhiza formation and Ecology. Acta Universitatis Upsaliensis. Comprehensive Summaries of Uppsala Dissertations from the Faculty of Science and Technology 35. Uppsala: Swedish University of Agricultural Sciences, 75.

Danell, E., Alström, S., and Ternström, A. (1993). Pseudomonas fluorescens in association with fruit bodies of the ectomycorrhizal mushroom Cantharellus cibarius. Mycol. Res. 97, 1148-1152. doi: 10.1016/S0953-7562(09)80519-4

De Boer, W., Folman, L. B., Summerbell, R. C., and Boddy, L. (2005). Living in a fungal world: Impact of fungi on soil bacterial niche development. FEMS Microbiol. Rev. 29, 795-811. doi: 10.1016/j.femsre.2004.11.005

de Carvalho, M. P., Türck, P., and Abraham, W. R. (2015). Secondary metabolites control the associated bacterial communities of Saprophytic Basidiomycotina fungi. Microbes Environ. 30, 196-198. doi: 10.1264/jsme2.ME14139

Deveau, A., Antony-Babu, S., Le Tacon, F., Robin, C., Frey-Klett, P., and Uroz, S. (2016). Temporal changes of bacterial communities in the Tuber melanosporum ectomycorrhizosphere during ascocarp development. Mycorrhiza 26, 389-399. doi: 10.1007/s00572-015-0679-7

Drewnowska, M., and Falandysz, J. (2015). Investigation on mineral composition and accumulation by popular edible mushroom common chanterelle (Cantharellus cibarius). Ecotoxicol. Environ. Saf. 113, 9-17. doi: 10.1016/j. ecoenv.2014.11.028

Eckburg, P. B., Bik, E. M., Bernstein, C. N., Purdom, E., Dethlefsen, L., Sargent, M., et al. (2006). Diversity of the human intestinal microbial flora. Science 308, 1635-1638. doi: 10.1126/science.1110591

Fan, L., Reynolds, D., Liu, M., Stark, M., Kjelleberg, S., Webster, N. S., et al. (2012). Functional equivalence and evolutionary convergence in complex communities of microbial sponge symbionts. Proc. Natl. Acad. Sci. U.S.A. 109, E1878-E1887. doi: $10.1073 /$ pnas. 1203287109

Fierer, N., and Jackson, R. B. (2006). The diversity and biogeography of soil bacterial communities. Proc. Natl. Acad. Sci. U.S.A. 103, 626-631. doi: 10.1073/ pnas.0507535103

Frey-Klett, P., Garbaye, J., and Tarkka, M. (2007). The mycorrhiza helper bacteria revisited. New Phytol. 176, 22-36. doi: 10.1111/j.1469-8137.2007.02191.x

Grice, E. A., Kong, H. H., Conlan, S., Deming, C. B., Davis, J., Young, A. C., et al. (2009). Topographical and temporal diversity of the human skin microbiome. Science 324, 1190-1192. doi: 10.1126/science.1171700

Grube, M., Cardinale, M., de Castro, jr. J. V, Müller, H., and Berg, G. (2009). Species-specific structural and functional diversity of bacterial communities in lichen symbiosis. ISME J. 3, 1105-1115. doi: 10.1038/ismej.2009.63

Gryndler, M., Soukupová, L., Hršelová, H., Gryndlerova, H., Borovièka, J., Streiblová, E., et al. (2013). A quest for indigenous truffle helper prokaryotes. Environ. Microbiol. Rep. 5, 346-352. doi: 10.1111/1758-2229.12014

Hacquard, S., Garrido-Oter, R., Gonzalez, A., Spaepen, S., Ackermann, G., Lebeis, S., et al. (2015). Microbiota and host nutrition across Plant and Animal Kingdoms. Cell Host Microbe 17, 603-616. doi: 10.1016/j.chom.2015.04.009

Hacquard, S., and Schadt, C. W. (2014). Tansley insight: towards a holistic understanding of the beneficial interactions across the Populus microbiome. New Phytol. 205, 1424-1430. doi: 10.1111/nph.13133

Hildebrand, F., Tadeo, R., Voigt, A. Y., Bork, P., and Raes, J. (2014). LotuS?: an efficient and user-friendly OTU processing pipeline. Microbiome 2:30. doi: 10.1186/2049-2618-2-30

Hoppe, B., Kahl, T., Karasch, P., Wubet, T., Bauhus, J., Buscot, F., et al. (2014). Network analysis reveals ecological links between $\mathrm{N}$-fixing bacteria and wooddecaying fungi. PLoS ONE 9:e88141. doi: 10.1371/journal.pone.0088141

Huang, Y., Niu, B., Gao, Y., Fu, L., and Li, W. (2010). CD-HIT Suite: a web server for clustering and comparing biological sequences. Bioinform. Appl. Note 26, 680-682. doi: 10.1093/bioinformatics/btq003

Hyde, E. R., Navas-Molina, J. A., Song, S. J., Kueneman, J. G., Ackermann, G., Cardona, C., et al. (2016). The oral and skin microbiomes of captive komodo dragons are significantly shared with their habitat. mSystems 1:e00046-16. doi: $10.1128 / \mathrm{mSystems.00046-16}$
Iffis, B., St-Arnaud, M., and Hijri, M. (2016). Petroleum hydrocarbon contamination, plant identity and arbuscular mycorrhizal fungal community determine assemblages of the AMF spore-associated microbes. Environ. Microbiol. 18, 2689-2704. doi: 10.1111/1462-2920.13438

Jayasinghearachchi, H. S., and Seneviratne, G. (2004). Can mushrooms fix atmospheric nitrogen? J. Biosci. 29, 293-296. doi: 10.1007/BF02702611

Jeon, Y. S., Chun, J., and Kim, B. S. (2013). Identification of household bacterial community and analysis of species shared with human microbiome. Curr. Microbiol. 67, 557-563. doi: 10.1007/s00284-013-0401-y

Kataoka, R., Siddiqui, Z. A., Kikuchi, J., Ando, M., Sriwati, R., Nozaki, A., et al. (2012). Detecting nonculturable bacteria in the active mycorrhizal zone of the pine mushroom Tricholoma matsutake. J. Microbiol. 50, 199-206. doi: 10.1007/ s12275-012-1371-7

Kataoka, R., Taniguchi, T., Ooshima, H., and Futai, K. (2008). Comparison of the bacterial communities established on the mycorrhizae formed on Pinus thunbergii root tips by eight species of fungi. Plant Soil 304, 267-275. doi: 10.1007/s11104-008-9548-x

Kumari, D., Reddy, M. S., and Upadhyay, R. C. (2013). Diversity of cultivable bacteria associated with fruiting bodies of wild Himalayan Cantharellus spp. Ann. Microbiol. 63, 845-853. doi: 10.1007/s13213-012-0535-3

Larsson, A. (2014). AliView : a fast and lightweight alignment viewer and editor for large datasets. Bioinform. Appl. Note 30, 3276-3278. doi: 10.1093/ bioinformatics/btu531

Lauber, C. L., Hamady, M., Knight, R., and Fierer, N. (2009). Pyrosequencing-based assessment of soil $\mathrm{pH}$ as a predictor of soil bacterial community structure at the continental scale. Appl. Environ. Microbiol. 75, 5111-5120. doi: 10.1128/AEM. 00335-09

Marupakula, S., Mahmood, S., and Finlay, R. D. (2015). Analysis of single root tip microbiomes suggests that distinctive bacterial communities are selected by Pinus sylvestris roots colonized by different ectomycorrhizal fungi. Environ. Microbiol. 18, 1470-1483. doi: 10.1111/1462-2920.13102

Munsch, P., Alatossava, T., Marttinen, N., Meyer, J. M., Christen, R., and Gardan, L. (2002). Pseudomonas costantinii sp. nov., another causal agent of brown blotch disease, isolated from cultivated mushroom sporophores in Finland. Int. J. Syst. Evol. Microbiol. 52, 1973-1983. doi: 10.1099/00207713-52-6-1973

Nazir, R., Warmink, J. A., Boersma, H., and van Elsas, J. D. (2010). Mechanisms that promote bacterial fitness in fungal-affected soil microhabitats. FEMS Microbiol. Ecol. 71, 169-185. doi: 10.1111/j.1574-6941.2009.00807.x

Noble, R., Dobrovin-Pennington, A., Hobbs, P. J., Pederby, J., and Rodger, A. (2009). Volatile C8 compounds and pseudomonads influence primordium formation of Agaricus bisporus. Mycologia 101, 583-591. doi: 10.3852/07-194

Paul, L. R., Chapman, B. K., and Chanway, C. P. (2007). Nitrogen fixation associated with Suillus tomentosus tuberculate ectomycorrhizae on Pinus contorta var. latifolia. Ann. Bot. 99, 1101-1109. doi: 10.1093/aob/mcm061

Poole, E. J., Bending, G. D., Whipps, J. M., and Read, D. J. (2001). Bacteria associated with Pinus sylvestris-Lactarius rufus ectomycorrhizas and their effects on mycorrhiza formation in vitro. New Phytol. 151, 743-751. doi: 10.1046/j.0028-646x.2001.00219.x

Quandt, C. A., Kohler, A., Hesse, C. N., Sharpton, T. J., Martin, F., and Spatafora, J. W. (2015). Metagenome sequence of Elaphomyces granulatus from sporocarp tissue reveals Ascomycota ectomycorrhizal fingerprints of genome expansion and Proteobacteria-rich microbiome. Environ. Microbiol. 17, 2952-2968. doi: 10.1111/1462-2920.12840

Rangel-Castro, J. I., and Danell, E. (2002). A 13C-NMR study of exudation and storage of carbohydrates and amino acids in the ectomycorrhizal edible mushroom Cantharellus cibarius. Mycologia 94, 190-199. doi: 10.1080/ 15572536.2003.11833224

Rangel-Castro, J. I., Levenfors, J. J., and Danell, E. (2002a). Physiological and genetic characterization of fluorescent Pseudomonas associated with Cantharellus cibarius. Can. J. Microbiol. 48, 739-748.

Rangel-Castro, J. I., Staffas, A., and Danell, E. (2002b). The ergocalciferol content of dried pigmented and albino Cantharellus cibarius fruit bodies. Mycol. Res. 106, 70-73. doi: 10.1017/S0953756201005299

Riedlinger, J., Schrey, S. D., Tarkka, M. T., Hampp, R., Kapur, M., and Fiedler, H. P. (2006). Auxofuran, a novel metabolite that stimulates the growth of fly agaric, is produced by the mycorrhiza helper bacterium Streptomyces strain AcH 505. Appl. Environ. Microbiol. 72, 3550-3557. doi: 10.1128/AEM.72.5.3550-3557. 2006 
Rousk, J., Baath, E., Brookes, P. C., Lauber, C. L., Lozupone, C., Caporaso, J. G., et al. (2010). Soil bacterial and fungal communities across a $\mathrm{pH}$ gradient in an arable soil. ISME J. 4, 1340-1351. doi: 10.1038/ismej.2010.58

Saidi, N., Deshaware, S., Romdhane, I. B., Nadim, M., Ojamo, H., Kremer, R., et al. (2015). Endogenous bacteria of Tuber aestivum ascocarps are potential biocontrol agents of microbial post-harvest deterioration of truffles. Int. J. Eng. Appl. Sci. 7, 97-106.

Sbrana, C., Agnolucci, M., Bedini, S., Lepera, A., Toffanin, A., Giovannetti, M., et al. (2002). Diversity of culturable bacterial populations associated to Tuber borchii ectomycorrhizas and their activity on T. borchii mycelial growth. FEMS Microbiol. Lett. 211, 195-201. doi: 10.1111/j.1574-6968.2002.tb11224.x

Splivallo, R., Deveau, A., Valdez, N., Kirchhoff, N., Frey-Klett, P., and Karlovsky, P. (2014). Bacteria associated with truffle-fruiting bodies contribute to truffle aroma. Environ. Microbiol. 17, 2647-2660. doi: 10.1111/1462-2920.12521

Stefani, F. O. P., Bell, T. H., Marchand, C., de la Providencia, I. E., Yassimi, A. E., St-Arnaud, M., et al. (2015). Culture-dependent and -independent methods capture different microbial community fractions in hydrocarbon-contaminated soils. PLoS ONE 10:e0128272. doi: 10.1371/journal.pone.0128272

Tedersoo, L., Bahram, M., Põlme, S., Kõljalg, U., Yorou, N. S., Wijesundera, R., et al. (2014). Global diversity and geography of soil fungi. Science 346:1256688. doi: 10.1126/science. 1256688

Tedersoo, L., Naadel, T., Bahram, M., Pritsch, K., Buegger, F., Leal, M., et al. (2012). Enzymatic activities and stable isotope patterns of ectomycorrhizal fungi in relation to phylogeny and exploration types in an afrotropical rain forest. New Phytol. 195, 832-843. doi: 10.1111/j.1469-8137.2012.04217.x

Timonen, S., Jorgensen, K. S., Haahtela, K., and Sen, R. (1998). Bacterial community structure at defined locations of Pinus sylvestris - Suillus bovinus and Pinus sylvestris - Paxillus involutus mycorrhizospheres in dry pine forest humus and nursery peat. Can. J. Microbiol. 44, 499-513. doi: 10.1139/cjm-446-499

Torsvik, V., and Øvreås, L. (2002). Microbial diversity and function in soil: from genes to ecosystems. Curr. Opin. Microbiol. 5, 240-245. doi: 10.1016/S13695274(02)00324-7

Trias, R., Badosa, E., Montesinos, E., and Baeras, L. (2008). Bioprotective Leuconostoc strains against Listeria monocytogenes in fresh fruits and vegetables. Int. J. Food Microbiol. 127, 91-98. doi: 10.1016/j.ijfoodmicro.2008.06.011

Tsukamoto, T., Murata, H., and Shirata, A. (2002). Identification of nonpseudomonad bacteria from fruit bodies of wild agaricales fungi that detoxify tolaasin produced by Pseudomonas tolaasii. Biosci. Biotechnol. Biochem. 66, 2201-2208. doi: 10.1271/bbb.66.2201

Uroz, S., Oger, P., Morin, E., and Frey-Klett, P. (2012). Distinct ectomycorrhizospheres share similar bacterial communities as revealed by pyrosequencing-based analysis of 16S rRNA genes. Appl. Environ. Microbiol. 78, 3020-3024. doi: 10.1128/AEM.06742-11
Vandenkoornhuyse, P., Quaiser, A., Duhamel, M., Le Van, A., and Dufresne, A. (2015). Tansley review: the importance of the microbiome of the plant holobiont. New Phytol. 206, 1196-1206. doi: 10.1111/nph.13312

Vaz-Moreira, I., Egas, C., Nunes, O. C., and Manaia, C. M. (2011). Culturedependent and culture-independent diversity surveys target different bacteria: a case study in a freshwater sample. Antonie Van Leeuwenhoek 100, 245-257. doi: 10.1007/s10482-011-9583-0

Vik, U., Logares, R., Blaalid, R., Halvorsen, R., Carlsen, T., Bakke, I., et al. (2013). Different bacterial communities in ectomycorrhizae and surrounding soil. Sci. Rep. 3:3471. doi: 10.1038/srep03471

Vitali, B., Minervini, G., Rizzello, C. G., Spisni, E., Maccaferri, S., Brigidi, P., et al. (2012). Novel probiotic candidates for humans isolated from raw fruits and vegetables. Food Microbiol. 31, 116-125. doi: 10.1016/j.fm.2011. 12.027

Warmink, J. A., Nazir, R., and Van Elsas, J. D. (2009). Universal and species-specific bacterial 'fungiphiles' in the mycospheres of different basidiomycetous fungi. Environ. Microbiol. 11, 300-312. doi: 10.1111/j.1462-2920.2008.01767.x

Yarza, P., Yilmaz, P., Pruesse, E., Glöckner, O., Ludwig, W., Schleifer, K.-H., et al. (2014). Uniting the classification of cultured and uncultured bacteria and archaea using 16S rRNA gene sequences. Nat. Rev. 12, 635-645. doi: 10.1038/ nrmicro3330

Yun, Y. B., Park, S. W., Cha, J. S., and Kim, Y. K. (2013). Biological characterization of various strains of Pseudomonas tolaasii that causes brown blotch disease. J. Korean Soc. Appl. Biol. Chem. 56, 41-45. doi: 10.1007/s13765-0122242-y

Zagriadskaia, Y. A., Lysak, L. V., Sidorova, I. I., Aleksandrova, A. V., and Voronina, E. Y. (2013). Bacterial complexes of the fruiting bodies and hyphosphere of certain basidiomycetes. Biol. Bull. 40, 358-364. doi: 10.1134/ S106235901304016X

Zaranejad, F., Yakhchali, B., and Rasooli, I. (2012). Evaluation of indigenous potent mushroom growth promoting bacteria (MGPB) on Agaricus bisporus production. World J. Microbiol. Biotechnol. 28, 99-104. doi: 10.1007/s11274011-0796-1

Conflict of Interest Statement: The authors declare that the research was conducted in the absence of any commercial or financial relationships that could be construed as a potential conflict of interest.

Copyright (c) 2017 Pent, Põldmaa and Bahram. This is an open-access article distributed under the terms of the Creative Commons Attribution License (CC BY). The use, distribution or reproduction in other forums is permitted, provided the original author(s) or licensor are credited and that the original publication in this journal is cited, in accordance with accepted academic practice. No use, distribution or reproduction is permitted which does not comply with these terms. 